\title{
Analisis dan Perancangan Sistem Informasi Panduan Kesehatan Balita Menggunakan Metode IMT/U
}

\author{
Merryana Lestari $^{1}$, Eko Sediyono $^{2}$ \\ 1,2Magister Sistem Informasi, Fakultas Teknologi Informasi, \\ Universitas Kristen Satya Wacana, Salatiga, Indonesia \\ Email: 1972020011@student.uksw.edu, 2eko@uksw.edu
}

\begin{abstract}
Immunization, nutritional support for food vitamins and nutritional content from food are important components to support good children's growth and development. However, the number of malnutrition and malnutrition in Indonesia is still high, causing many children under five to experience stunting during the golden age. Due to various factors, the interest of parents to bring their children to Posyandu is decreasing. Through this research, analysis and design of mobile-based information systems that can be accessed anywhere and anytime as needed is carried out. The results of this study are a practical solution for parents to be able to monitor the health of their toddlers on the sidelines of their busy life, namely with a toddler health guidance system that can be accessed via a smartphone. This information system design can be used as a guide for parents regarding the child's health information needed. especially in the period of growth and development of children under five by monitoring growth curves and providing health recommendations through the calculation of the Body Mass Index (BMI) for toddlers and can also be used as a reminder and recording of immunization data for children under five.
\end{abstract}

Keywords: information system, children under five, BMI, immunization, prototype.

\section{PENDAHULUAN}

Gizi pada masa pertumbuhan dan perkembangan anak pada usia golden age sangat berperan penting dalam perkembangan otak dan proporsional tubuh pada saat anak menjelang dewasa. Oleh karena itu, pemantauan kesehatan anak khususnya pada usia balita menjadi sangat penting. Saat ini, di Indonesia, dalam beberapa dekade ini Indonesia mengalami penurunan masalah kekurangan gizi, namun kekurangan gizi akut dan kronis masih cukup tinggi. Data nasional memperlihatkan adanya 36,8\% anak usia bawah lima tahun (balita) yang mengalami stunting (pendek dan sangat pendek, diukur dengan tinggi badan menurut umur). Indikator ini menunjukkan terjadinya kekurangan gizi dalam jangka waktu yang panjang atau kronis yang dikarenakan tingginya angka kesakitan 
atau rendahnya asupan makanan. Prevalensi balita yang mengalami kekurangan gizi akut (gizi kurang dan gizi buruk, diukur dengan berat badan menurut umur) sebesar 18,4\% dan prevalensi nasional balita kurus (wasting-serius) dan balita sangat kurus (wasting-kritis), yang diukur menurut berat badan menurut tinggi adalah 14,6\% [1]. Hal tersebut disebabkan karena berbagai faktor, salah satunya adalah berkurangnya minat orang tua untuk membawa anaknya ke Posyandu.

Setiap anak berhak atas kelangsungan hidup, tumbuh dan berkembang serta berhak atas perlindungan dari kekerasan dan diskriminasi, sehingga perlu dilakukan upaya kesehatan anak secara terpadu, menyeluruh, dan berkesinambungan [2]. Kategori anak sebagai berikut: 1) Anak adalah seseorang yang sampai berusia 18 tahun, termasuk anak yang masih dalam kandungan, 2) Bayi Baru Lahir adalah bayi umur 0 sampai dengan 28 hari, 3) Bayi adalah anak mulai umur 0 sampai 11 bulan, 4) Anak Balita adalah anak umur 12 bulan sampai dengan 59 bulan, 5) Anak Prasekolah adalah anak umur 60 bulan sampai 72 bulan, 6) Anak Usia Sekolah adalah anak umur lebih dari 6 tahun sampai sebelum berusia 18 tahun, dan 7) Remaja adalah kelompok usia 10 tahun sampai berusia 18 tahun [3]. Oleh karena itu, diperlukannya sebuah solusi praktis untuk orang tua untuk dapat melakukan pemantauan kesehatan anak balitanya disela-sela kesibukannya, yaitu dengan sebuah sistem panduan kesehatan balita yang dapat diakses melalui smartphone.

Penelitian sebelumnya yang terkait dengan penelitian ini yaitu dengan judul: "Analysis and Design of Restaurant Information System using Unified Modeling Language" yang dilakukan oleh Wijaya, dkk. (2019). Penelitian tersebut dilakukan dengan tujuan untuk memudahkan admin dalam mengolah data persediaan bahan baku outlet dan gudang yang berada di berbagai kota. Metode yang digunakan adalah metode System Development Life Cycle (SDLC), yaitu metode yang menggunakan beberapa tahapan dalam pengembangan sistem mulai dari Perencanaan Sistem, Analis Sistem, Perancangan Sistem, Implementasi Sistem, Implementasi Sistem, dan Pemeliharaan Sistem. Hasil dari penelitian ini adalah sebuah sistem yang dapat diakses oleh admin untuk memudahkan proses kerja [4].

Penelitian lainnya yang terkait yaitu berjudul: "Designing of KB (Family Planning) Service Information System in Pratama Clinic Salatiga" yang dilakukan oleh Tanaem, dkk. Penelitian tersebut bertujuan untuk menjelaskan perancangan sistem informasi pelayanan Keluarga Berencana (KB) yang tersedia di Klinik Pratama Salatiga. Adapun latar belakang penelitian ini karena Indonesia merupakan salah satu negara dengan jumlah penduduk terbesar di dunia dan hal ini terjadi karena jumlah kelahiran di Indonesia yang tidak dapat dikendalikan. Meski pemerintah telah mencanangkan $\mathrm{KB}$ yang diaplikasikan dengan menggunakan alat kontrasepsi, namun belum mampu mengatasi permasalahan yang terjadi. Banyaknya kelahiran 
yang tidak terkontrol ini dikarenakan banyaknya keluarga yang mengeluhkan penggunaan alat kontrasepsi. Mahal, sulit didapat dan tidak nyaman saat digunakan menjadi alasan bagi mereka yang tidak mau menggunakan kontrasepsi sehingga jumlah kelahiran tidak bisa dikontrol, selain itu seiring dengan berkembangnya pelayanan KB yang sudah ada semakin diabaikan karena masyarakat lebih menyukai hal-hal yang Praktis dan tidak suka mengikuti program atau layanan yang berbelit-belit seperti pelayanan $\mathrm{KB}$ sehingga menyebabkan semakin banyak masyarakat yang malas menghadiri KB dan berdampak pada meningkatnya angka kelahiran. Melihat fenomena tersebut, maka terbentuk pemikiran bahwa sistem informasi pelayanan sangat dibutuhkan di era pembangunan saat ini, terutama untuk memudahkan segala pekerjaan yang tidak dapat diselesaikan dalam waktu singkat. Maka, dibuatlah perancangan sistem informasi khusus bidang pelayanan KB di Klinik Pratama Salatiga. Dalam penelitian ini dijelaskan tentang bagaimana pelayanan KB dapat diakses dengan mudah tanpa membuang banyak waktu sehingga masyarakat ingin berpartisipasi dalam pelayanan KB. Salah satu cara yang dapat dilakukan adalah dengan membangun sistem informasi yang dapat digunakan untuk pelayanan KB dengan sistem yang mudah dipahami dan diakses oleh masyarakat luas [5].

Berdasarkan hasil penelitian sebelumnya, maka pada penelitian ini dilakukan perancangan sistem informasi berbasis mobile yang dapat diakses dimana saja dan kapan saja sesuai kebutuhan. Desain rancangan sistem informasi ini dapat digunakan sebagai panduan untuk ibu-ibu muda mengenai informasi kesehatan anak yang diperlukan khususnya pada masa pertumbuhan dan perkembangan balita dengan melakukan monitoring kurva pertumbuhan dan memberikan saran rekomendasi kesehatan melalui perhitungan Indeks Masa Tubuh (IMT) pada balita dan dapat digunakan pula sebagai reminder serta pencatatan data imunisasi pada anak balita.

Unified Modelling Language (UML) adalah suatu alat untuk memvisualisasikan dan mendokumentasikan hasil analisa dan desain yang berisi sintak dalam memodelkan sistem secara visual [6]. Saat ini sebagian besar perancang sistem informasi memanfaatkan UML sebagai metode perancangan desain mereka. Diagram UML dalam sebuah perancangan sistem informasi biasanya cukup didesain sebanyak 7 buah diagram yang terdiri dari: Usecase Diagram, Activity Diagram, Class Diagram, Sequence Diagram, Collaboration Diagram, Component Diagram, dan Deployment Diagram. Berikut tujuan utama dalam perancangan desain UML [7]:

1. Menyediakan bagi pengguna (analisis dan desain sistem) suatu bahasa pemodelan visual yang ekspresif sehingga mereka dapat mengembangkan dan melakukan pertukaran model data yang bermakna.

2. Menyediakan mekanisme yang spesialisasi untuk memperluas konsep inti. 
3. Karena merupakan bahasa pemodelan visual dalam proses pembangunannya maka UML bersifat independen terhadap bahasa pemrograman tertentu.

4. Memberikan dasar formal untuk pemahaman bahasa pemodelan.

5. Mendorong pertumbuhan pasar terhadap penggunaan alat desain sistem yang berorientasi objek.

6. Mendukung konsep pembangunan tingkat yang lebih tinggi seperti kolaborasi, kerangka, pola dan komponen terhadap suatu sistem.

7. Memiliki integrasi praktik terbaik.

Dalam langkah-langkah penggunaan UML, Batasan sistem harus ditentukan terlebih dahulu, tujuannya agar pemakai mengetahui dengan lingkungan mana saja sistem mereka berhubungan, untuk itu setiap komponen actor, (sumber atau tujuan) ini harus diberi nama sesuai dengan lingkungan luar yang mempengaruhi sistem tersebut. Berikut ini tahapan penggunaan UML [8]:

1. Buatlah daftar business process dari level tertinggi untuk mendefinisikan aktivitas dan proses yang mungkin muncul dengan menentukan item-item data apa saja yang akan ditempatkan dalam sistem.

2. Petakan use case untuk tiap business process untuk mendefinisikan dengan tepat fungsionalitas yang harus disediakan oleh sistem. Kemudian perhalus use case diagram dan lengkapi dengan requirement, constraints dan catatan-catatan lain.

3. Buatlah deployment diagram secara kasar untuk mendefinisikan arsitektur fisik sistem.

4. Definisikan requirement lain (non-fungsional, security dan sebagainya) yang juga harus disediakan oleh sistem.

5. Berdasarkan use case diagram, mulailah membuat activity diagram.

6. Definisikan objek-objek level atas (package atau domain) dan buatlah sequence dan/atau collaboration diagram untuk tiap alir pekerjaan. Jika sebuah use case memiliki kemungkinan alir normal dan error, buatlah satu diagram untuk masing-masing alir.

7. Buatlah rancangan user interface model yang menyediakan antarmuka bagi pengguna untuk menjalankan skenario use case.

8. Berdasarkan model-model yang sudah ada, buatlah class diagram. Setiap package atau domain dipecah menjadi hirarki class lengkap dengan atribut dan metodenya. Akan lebih baik jika untuk setiap class dibuat unit test untuk menguji fungsionalitas class dan interaksi dengan class lain.

9. Setelah class diagram dibuat, kita dapat melihat kemungkinan pengelompokan class.

\section{METODOLOGI PENELITIAN}

Pengukuran IMT dapat dilakukan pada anak-anak, remaja maupun orang dewasa. Pada anak-anak dan remaja pengukuran IMT sangat terkait dengan umurnya, 
karena dengan perubahan umur terjadi perubahan komposisi tubuh dan densitas tubuh. Karena itu, pada anak-anak dan remaja digunakan indikator IMT menurut umur, biasa disimbolkan dengan IMT/U. IMT adalah perbandingan antara berat badan dengan tinggi badan kuadrat [9]. Cara pengukurannya adalah pertama-tama ukur berat badan dan tinggi badannya. Indek Massa Tubuh (IMT) adalah parameter yang ditetapkan oleh WHO (Badan Kesehatan Dunia) sebagai perbandingan berat badan dengan kuadrat tinggi badan [10]. IMT pada anak usia dibawah 5 tahun ditentukan dengan cara mengukur berat badan ideal berdasarkan umur (IMT/U). Pendekatan yang digunakan dalam penelitian ini yaitu metode deskriptif kuantitatif dengan menggunakan metode perhitungan IMT/U melalui persamaan sebagai berikut:

$$
\begin{aligned}
& \text { BBI = BBL }(\mathbf{g r})+(\mathbf{U s i a} \times \mathbf{6 0 0} \text { gram }) \\
& \text { Keterangan : } \\
& \mathrm{BBI}=\text { Berat Badan Ideal } \\
& \mathrm{BBL}=\text { Berat Badan Lahir dalam satuan gram } \\
& \mathrm{Usia}=\text { Usia bayi dalam satuan bulan }
\end{aligned}
$$

Gambar 1. Rumus IMT/U Bayi usia 0-6 bulan

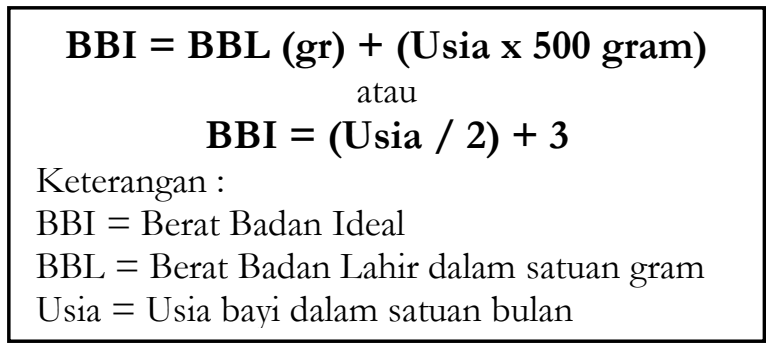

Gambar 2. Rumus IMT/U Bayi usia 7-12 bulan

\begin{tabular}{l}
\hline BBI $=2 \mathbf{n}+\mathbf{8}$ \\
Keterangan: \\
BBI = Berat Badan Ideal \\
$\mathrm{n}=$ Usia anak dalam satuan tahun \\
Gambar 3. Rumus IMT/U anak usia 1-5 tahun
\end{tabular}

Hasil perhitungan Berat Badan Ideal (BBI) pada gambar 1, gambar 2 dan gambar 3 dihitung dalam satuan Kilogram (Kg). Untuk gambar 1 dan gambar 2, data berat badan dihitung dalam satuan gram (gr), usia dihitung dalam satuan bulan. Sedangkan BBI pada gambar 3 perhitungannya sedikit berbeda karena usia 
Vol. 3, No. 1, March 2021

p-ISSN: 2656-5935 http://journal-isi.org/index.php/isi e-ISSN: 2656-4882

anak yang akan dihitung dalam satuan tahun. Data BBI yang didapatkan dalam perhitungan akan ditampilkan, dianalisis dalam pencocokan nilai BBI pada tabel Standar Indeks Massa Tubuh menurut Umur (IMT/U) untuk mendapatkan kriteria gizi kondisi anak saat ini yang terdapat pada gambar 4. Pada Tabel Standar Indeks Massa Tubuh menurut Umur (IMT/U) terdapat pembedaan nilai BBI berdasarkan jenis kelamin dan terdapat pula 4 klasifikasi kriteria status gizi yaitu gizi buruk, gizi kurang, gizi baik dan gizi lebih. Untuk menentukan status gizi anak balita (usia 0-60 bulan), nilai IMT-nya harus dibandingkan dengan nilai IMT standar WHO 2005 [11]; sedangkan pada anak dan remaja usia 5-19 tahun nilai IMT-nya harus dibandingkan dengan referensi WHO/NCHS 2007 [12].

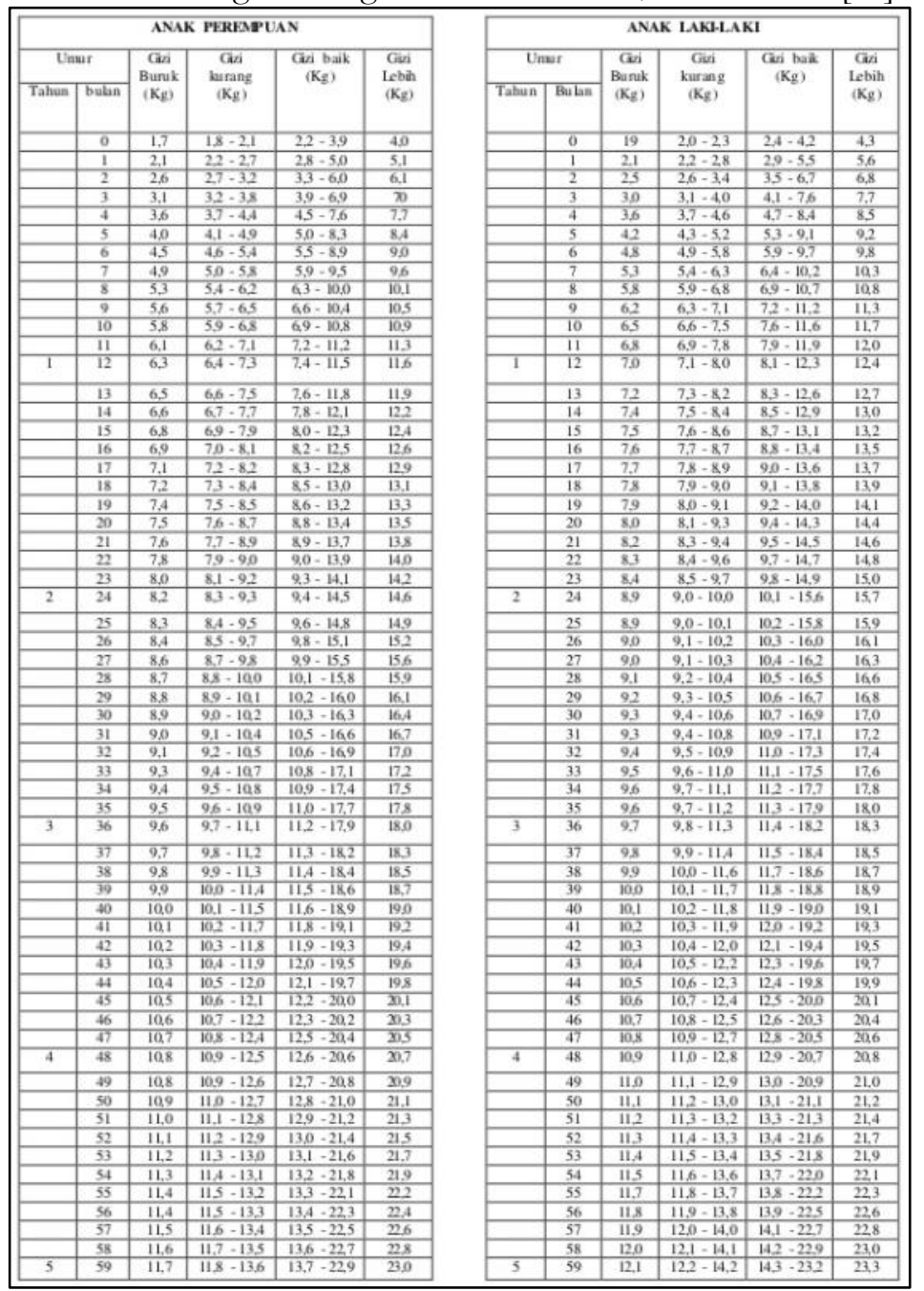

Gambar 4. Tabel Standar Indeks Massa Tubuh menurut Umur (IMT/U) 


\section{HASIL DAN PEMBAHASAN}

Guna mendapatkan manfaat dari sistem informasi ini, perancangan sistem ini harus memiliki beberapa kemampuan yaitu:

1. Dapat diakses dari mana saja dan kapan saja melalui berbagai platform (bersifat mobile based) menggunakan mobile application, dikarenakan populernya penggunaan smartphone diberbagai kalangan pada saat ini.

2. Pengguna dapat melakukan pendaftaran dan login ke sistem, dengan memasukan informasi data diri pengguna dan data anak balitanya.

Data-data tersebut akan digunakan nantinya oleh sistem untuk memonitoring pertumbuhan balita dan dapat memberikan saran rekomendasi kebutuhan gizi melalui rekomendasi makanan tambahan dan nutrisi vitamin yang tepat untuk balita, memberikan pengingat (reminder) jadwal imunisasi beserta pencatatan data imunisasi, dan sistem dapat memberikan informasi kebutuhan gizi balita, pentingnya ASI untuk bayi, jenis makanan pendukung (MPASI), nutrisi vitamin sesuai usia balita, serta tips-tips yang sangat berguna untuk penggunanya yaitu orang tua dan Posyandu.

Berdasarkan beberapa analisis kemampuan diatas maka diperoleh beberapa requirement berupa deskripsi aktor dan skenario usecase sebagai berikut:

1. Sistem ini dirancang berupa sistem mobile based menggunakan smartphone dengan platform Operating System Android.

2. Aktor yang terlibat pada sistem adalah pengguna dan administrator.

3. Pengguna adalah orang yang menggunakan sistem, dalam hal ini yaitu orang tua atau Posyandu.

4. Administrator adalah orang yang mengelola sistem, dalam hal ini diperlukan peran seorang administrator yang dapat mengoperasikan sistem, server based dan memahami operasional platform Android.

5. Sebelum menggunakan sistem, pengguna wajib melakukan pendaftaran pada sistem dengan menginputkan data diri pengguna dan data balita yang akan di pantau pertumbuhannya oleh sistem.

6. Setelah pengguna sukses melakukan pendaftaran pada sistem, apabila pengguna atau administrator akan masuk ke dalam sistem maka pengguna wajib melakukan proses login dan dilanjutkan dengan proses cek otentifikasi.

7. Setelah pengguna berhasil login maka akan menampilkan halaman utama yang berisi menu dari sistem berupa monitoring pertumbuhan, imunisasi, serta beranda yang berisi informasi-informasi yang bermanfaat untuk pengguna dalam pemantauan pertumbuhan dan perkembangan balita.

8. Sistem ini melakukan monitoring pertumbuhan anak dengan menggunakan perhitungan BBI sesuai keriteria umur, lalu membandingkannya dengan data pada tabel Standar Indeks Massa Tubuh menurut Umur (IMT/U) dan dari 
hasil perbandingan tersebut sistem dapat memberikan saran rekomendasi untuk peningkatan asupan gizi anak yang dapat berupa makanan dan vitamin tambahan apabila hasil dari monitoring pertumbuhan tersebut menghasilkan nilai kriteria gizi buruk, gizi kurang dan gizi lebih dari tabel acuan yang ideal yaitu gizi baik.

9. Sistem ini dapat melakukan pencatatan data imunisasi yang sudah dilakukan oleh anak balita pengguna, dan memberikan reminder imunisasi yang harus dilakukan berdasarkan perhitungan usia balita dibandingkan dengan tabel panduan imunisasi. Reminder imunisasi akan ditampilkan berupa notifikasi pada smartphone pengguna.

10. Pada bagian beranda, sistem ini juga dapat memberikan informasi ter-update secara berkala mengenai panduan-panduan ataupun tips-tips kesehatan balita.

11. Setelah administrator berhasil login maka akan menampilkan halaman pengelolaan sistem, administrator dapat melakukan proses pengelolaan data dengan melakukan penambahan, perubahan, penghapusan dan pencarian data. Beberapa menu data yang dapat dikelola adalah data pengguna, data tabel imunisasi, data tabel IMT/U, data rekomendasi kesehatan dan kelola beranda informasi.

12. Semua proses dalam sistem akan terintegrasi secara langsung dengan database server sehingga dapat diakses secara realtime.

13. Setelah pengguna ataupun administrator selesai menggunakan sistem, maka wajib melakukan proses logout dari sistem.

Melalui data requirement kebutuhan sistem diatas maka dapat dilakukan proses perancangan diagram UML untuk sistem informasi panduan kesehatan balita (EKIA) sebagai beriikut:

\section{Usecase Diagram}

Perancangan usecase diagram sistem informasi E-KIA pada Gambar 5 terdiri dari 2 (dua) aktor yaitu pengguna dan administrator. Pengguna dapat melakukan pendaftaran sebagai pengguna, login ke dalam sistem, me-monitoring pertumbuhan balita dan me-monitoring data imunisasi. Sedangkan, administrator dapat melakukan login ke dalam sistem sebagai administrator, mengelola data sistem informasi, antara lain seperti: mengelola tabel imunisasi, mengelola data pengguna, mengelola konten informasi kesehatan dan melakukan maintenance sistem. Sistem informasi ini memiliki kemampuan analisis perhitungan BBI menggunakan rumus IMT/U untuk memonitoring pertumbuhan dan memberikan saran rekomendasi berupa pemberian informasi makanan tambahan dan vitamin tambahan, serta memberikan reminder imunisasi. 
Vol. 3, No. 1, March 2021

p-ISSN: 2656-5935 http://journal-isi.org/index.php/isi $\quad$ e-ISSN: 2656-4882

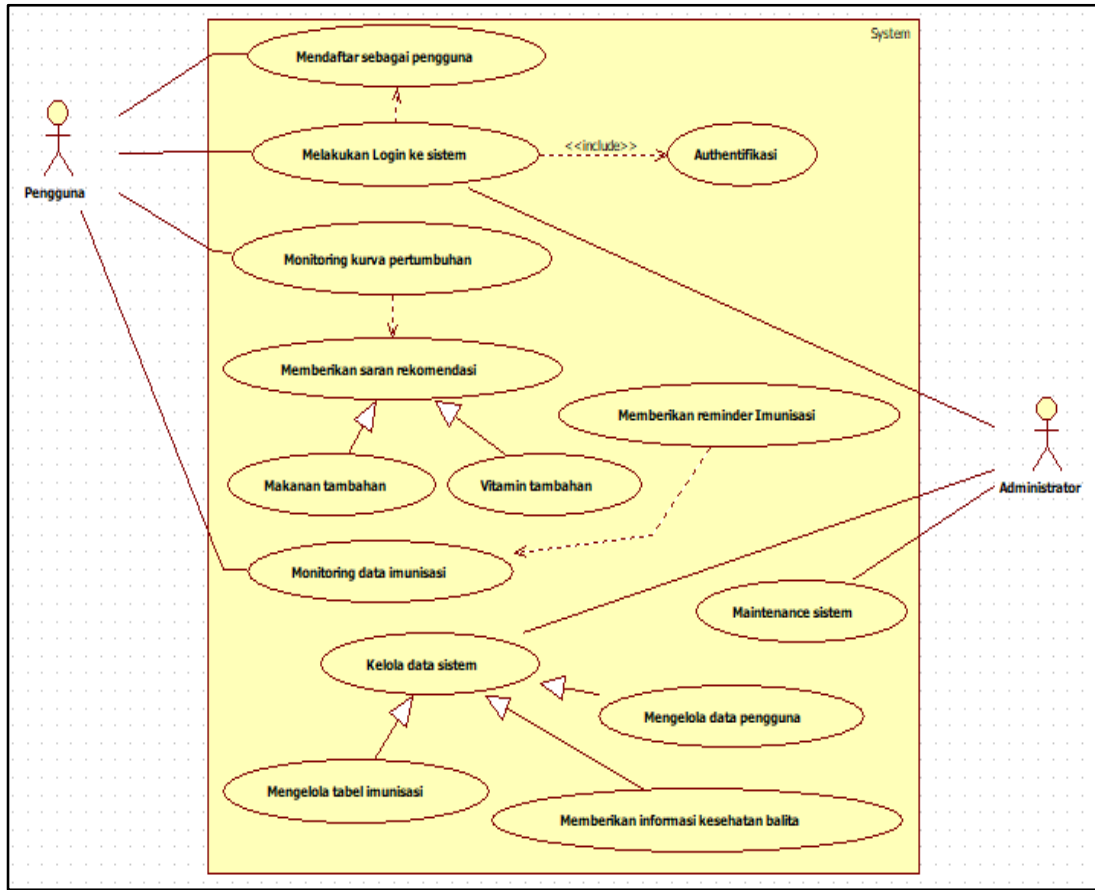

Gambar 5. Usecase Diagram E-KIA

\section{Class Diagram}

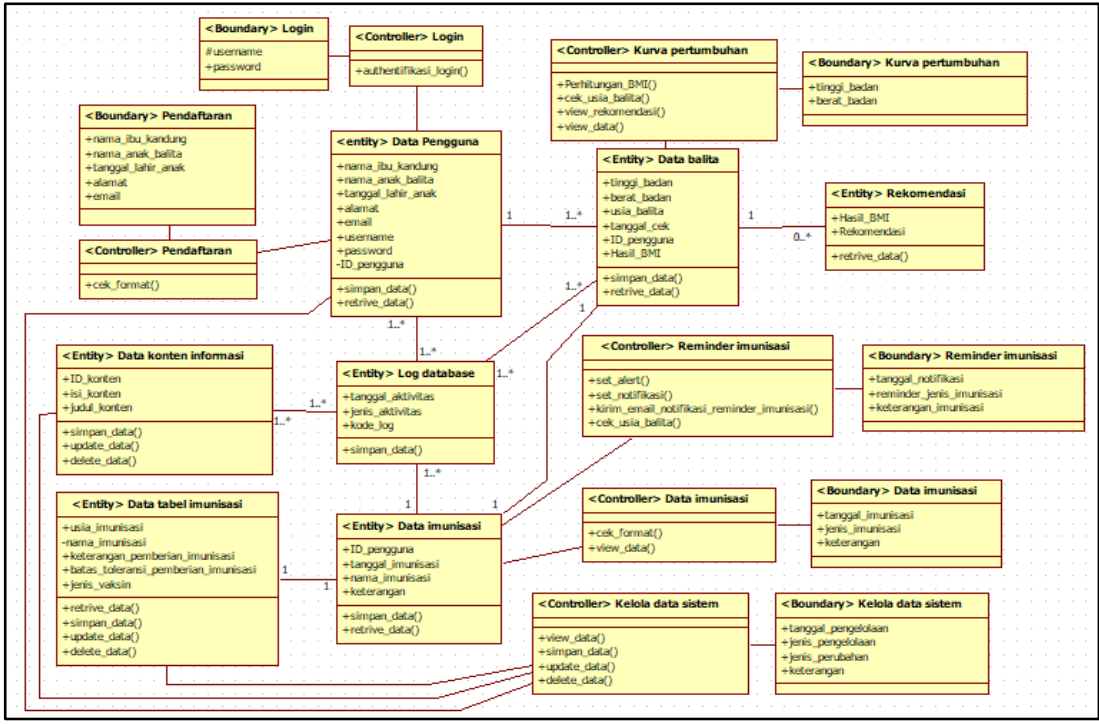

Gambar 6. Class Diagram E-KIA 
Vol. 3, No. 1, March 2021

p-ISSN: 2656-5935 http://journal-isi.org/index.php/isi

e-ISSN: 2656-4882

Gambar 6 menunjukkan class diagram sistem informasi E-KIA yang menjelaskan relasi atau hubungan antar objek yang saling bergantung sama lainnya. Terdapat class boundary yang berfungsi sebagai objek desain user interface yang akan ditampilkan, class controller berfungsi sebagai objek untuk menampung method, prosedur maupun fungsi yang akan dijalankan oleh sistem dan class controller yang berfungsi sebagai tempat penampung data atau database. Hubungan relasi pada class entity yang di gambarkan pada class diagram sistem informasi E-KIA menggambarkan seberapa banyak data yang dapat diproses.

\section{Deployment Diagram}

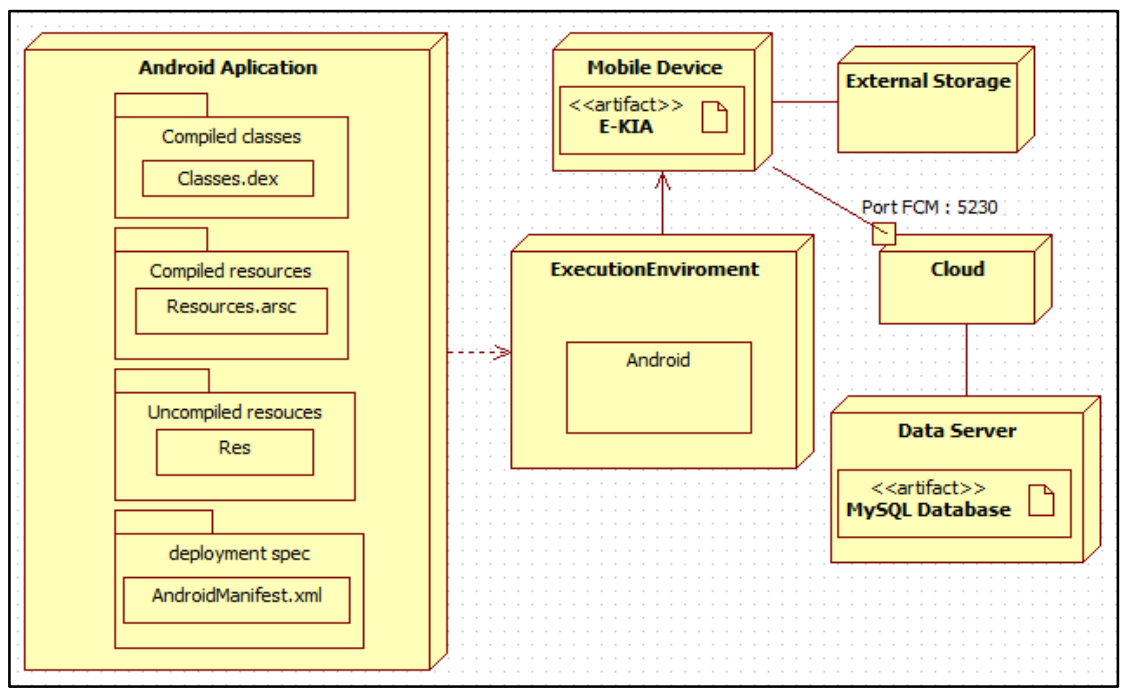

Gambar 7. Deployment Diagram E-KIA

Gambar 7 menujukkan deployment diagram sistem informasi E-KIA yang terdiri dari komponen Android Application yang merupakan application server, Mobile Device yang merupakan tempat dimana aplikasi E-KIA di-instal, dan komponen cloud yang menghubungkan dengan Database Server.

\section{Perancangan User Interface}

Perancangan user interface berfungsi untuk memberikan gambaran baik kepada pengembang sistem maupun calon pengguna sistem mengenai sistem informasi eKIA. Perancangan user interface mengacu kepada disain class diagram pada komponen class boundary. Disain user interface yang dibuat antara lain, yaitu: Form Login, Form Pendaftaran, Form Cek Pertumbuhan dan Rekomendasi, Form Data Imunisasi, Form Tambah Data Imunisasi, dan Form Reminder / Pengingat Imunisasi. 
Vol. 3, No. 1, March 2021

p-ISSN: 2656-5935 http://journal-isi.org/index.php/isi

e-ISSN: 2656-4882

\section{Form Cek Pertumbuhan dan Rekomendasi}

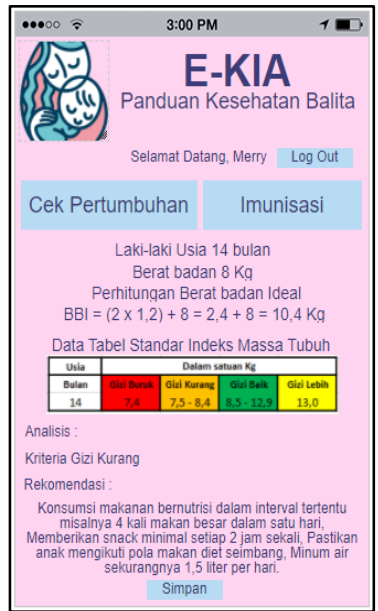

Gambar 8. Disain User Interface Form Cek Pertumbuhan dan Rekomendasi

Gambar 8 menujukkan disain user interface Form Cek Pertumbuhan dan Rekomendasi yang digunakan oleh pengguna untuk melihat data indeks gizi pertumbuhan anak balitanya berdasarkan rumus perhitungan Indeks Masa Tubuh berdasarkan Umur (IMT/U) hanya dengan memasukkan Berat Badan. Setelah data dimasukkan, maka akan dilakukan perhitungan berat badan ideal dan dibandingkan dengan tabel standar IMT/U, kemudian akan ditampilkan berupa hasil analisis, dan rekomendasi yang sesuai untuk pertumbuhan gizi anak balitanya.

\section{Form Data Imunisasi}

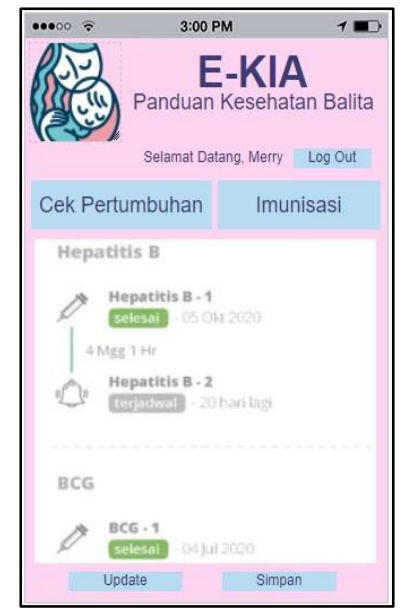

Gambar 9. Disain User Interface Form Data Imunisasi 
Gambar 9 menujukkan disain user interface Form Data Imunisasi yang digunakan oleh pengguna untuk melihat history data imunisasi yang telah dilakukan. Pada form ini terdapat tombol Update Data dan Simpan yang digunakan untuk memasukkan data imunisasi yang saat ini dilakukan.

\section{KESIMPULAN}

Sistem informasi E-KIA dirancang untuk menjadi solusi orang tua yang tidak dapat melakukan pengecekan kesehatan anak balita pada Posyandu setiap bulannya karena berbagai faktor dan sistem ini dapat menjadi sebuah panduan untuk mengetahui informasi kesehatan anak balita yang diperlukan khususnya pada masa pertumbuhan dan perkembangan balita dengan melakukan monitoring pertumbuhan dan memberikan saran rekomendasi kesehatan melalui perhitungan Indeks Masa Tubuh berdasarkan Umur (IMT/U) pada balita dan dapat digunakan pula sebagai reminder serta pencatatan data imunisasi pada anak balita. Perancangan yang dilakukan menggunakan tools Unified Modelling Language (UML) yang terdiri dari usecase, activity, class, sequence, dan deployment diagram dapat memberikan gambaran bagaimana sistem informasi E-KIA dapat diimplementasikan pada platform mobile application berbasis sistem operasi Android.

\section{DAFTAR PUSTAKA}

[1] Iswarawanti, D. N., 2010, “Kader Posyandu: Peranan dan Tantangan Pemberdayaannya dalam Usaha Peningkatan Gizi Anak di Indonesia". Jurnal Manajemen Pelayanan Kesehatan, Vol. 13, No. 4.

[2] Chusyairi, A., Pelsri R. N. S., 2019, "Rancang Bangun Sistem Informasi Kesehatan Bayi dan Balita Berbasis Android", Jurnal Teknologi Informasi, Vol. XIV No. 2.

[3] Mboi, N., 2014, "Peraturan Menteri Kesehatan Republik Indonesia Nomor 25 Tabun 2014 Tentang Upaya Kesehatan Anak", Jakarta.

[4] Wijaya, A. F., Rakhmawati, M. I., 2019, "Analysis and Design of Restaurant Information System using Unified Modeling Language”, SISFORMA Journal Vol. 6 No. 1.

[5] Tanaem, P. F., Wijaya, A. F., Kurniawati, F. W., Saputri, R., 2020, “Designing of KB (Family Planning) Service Information System in Pratama Clinic Salatiga", SISFORMA Journal Vol. 7 No. 1.

[6] Braun D., Sivils J., Shapiro A., Versteegh J., 2001, "Object Oriented Analysis and Design Team”, Kennesaw State University, CSIS 4650.

[7] Sugrue J., 2009, "Getting Started with UML", http://www.dzone.com/links/index.html.

[8] Haviluddin, 2011, "Memahami penggunaan UML (Unified Modelling Language)", Jurnal Informatika Mulawarman Vol. 6 No. 1. 


\section{Journal of Information Systems and Informatics}

Vol. 3, No. 1, March 2021

p-ISSN: 2656-5935 http://journal-isi.org/index.php/isi

e-ISSN: 2656-4882

[9] Situmorang, Marhaposan, 2015, "Penentuan Indeks Massa Tubub (IMT) melalui Pengukuran Berat dan Tinggi Badan Berbasis Mikrokontroler AT89S51 dan PC", Jurnal Teori dan Aplikasi Fisika Vol. 3 No. 2.

[10] Sarwono S., 2003, "Pedoman Praktis Memantau Status Giz̧i Orang Dewasa untuk Mempertahankan Berat Badan Normal Berdasarkan Indeks Massa Tubub”, Gramedia, Jakarta.

[11] WHO, 2006, “WHO Child Growth Standards”, WHO, Geneva.

[12] WHO Reference, 2007, "Child and Adolescent", WHO, Geneva. 